\title{
HOSPITALISASI MEMPENGARUHI TINGKAT KECEMASAN ANAK TODDLER
}

\author{
Zulhaini Sartika A. Pulungan ${ }^{1}$,Edi Purnomo ${ }^{1}$, Arni Purwanti A. ${ }^{2}$ \\ ${ }^{1}$ Jurusan Keperawatan Poltekkes Kemenkes Mamuju \\ ${ }^{2}$ Program Studi Sarjana Keperawatan Stikes Andini Persada Mamuju
}

\begin{abstract}
Hospitalization can cause anxiety and stress at all age levels. The cause of anxiety is influenced by many factors, both from the officer factor (nurses, doctors and other health personnel), the new environment, and the accompanying family during the treatment. Children sometimes perceive hospitalization as punishment so that children will feel shame, guilt, or fear. This leads to aggressive reactions such as anger and rebellion, verbal expression by saying angry words, not cooperating with nurses, thus affecting the treatment process while in hospital. The present study aimed at investigating the effect of hospitalization on anxiety levels of toddler in Puskesmas Tampa Padang. This research is an descriptive research with cross sectional design. Research subjects taken by purposive sampling counted 63 people. The data were analyzed using fisher's exact test. The results showed that hospitalization influenced toddler child's anxiety level (p 0.005). It is expected that health workers continue to provide good services and continue to maintain communication to children and families so that children feel comfortable during the process of hospitalization.
\end{abstract}

\section{Keywords: Children, toddler, hospitalization, anxiety}

\section{PENDAHULUAN}

Hospitalisasi pada anak merupakan proses karena suatu alasan yang berencana atau darurat mengharuskan anak untuk tinggal di rumah sakit menjalani terapi dan perawatan sampai pemulangan kembali kerumah. Selama proses tersebut, anak dapat mengalami berbagai kejadian yang menunjukan pengalaman yang sangat trauma dan penuh dengan stres. Hospitalisasi merupakan salah satu penyebab stress baik pada anak maupun keluarganya, terutama disebabkan oleh perpisahan dengan keluarga, kehilangan kendali, perlukaan tubuh dan rasa nyeri. Saat anak dirawat di rumah sakit (hospitalisasi) memaksa anak untuk berpisah dari lingkungan yang dirasakannya aman, penuh kasih sayang, dan menyenangkan,yaitu lingkungan rumah, permainan, dan teman sepermainannya (Nursalam, Susilaningrum, \& Utami, 2005; Supartini, 2004).

Populasi anak yang dirawat di rumah sakit mengalami peningkatan yang sangat dramatis dengan persentase yang lebih serius dan lebih kompleks bila dibandingkan dengan tahun-tahun sebelumnya. Berdasarkan survei dari WHO pada tahun 2008, hampir $80 \%$ anak mengalami perawatan di rumah sakit. TheNational Centre for Health Statistic memperkirakan bahwa 3 - 5 juta anak di bawah usia 15 tahun menjalani hospitalisasi setiap tahun. Angka kesakitan anak di Indonesia yang dirawat di rumah sakit cukup tinggi yaitu
$15,26 \%$ yang ditunjukkan dengan selalu penuhnya ruangan anak baik rumah sakit pemerintah maupun swasta. Bila dibandingkan angka kesakitan anak di daerah perdesaan dan perkotaan menunjukkan angka kesakitan di pedesaan lebih tinggi dibanding perkotaan $(15,75$ vs $14,74 \%)$. Berdasarkan survei kesehatan ibu dan anak tahun 2010 didapatkan hasil bahwa dari 1.425 anak mengalami dampak hospitalisasi: $33,2 \%$ diantaranya mengalami dampak hospitalisasi berat; $41,6 \%$ mengalami dampak hospitalisasi sedang; dan 25,2\% mengalami dampak hospitalisasi ringan. Keluhan kesehatan sebagai penyebab hospitalisasi adalah gangguan terhadap kondisi fisik maupun jiwa, termasuk kecelakaan yang dialami anak seperti panas, batuk, pilek, asma/napas sesak/cepat, diare/buang air, sakit kepala berulang, sakit gigi dan lainnya. Keluhan kesehatan yang dialami oleh balita memiliki kecenderungan yang sama di perkotaan dan perdesaan. Lebih dari separuh balita di Indonesia mengalami panas $(53,90$ persen), batuk (57,62 persen) dan pilek $(58,32$ persen). Ketiga keluhan kesehatan ini sering dialami balita, karena balita masih sangat rentan terhadap penyakit (Kementerian Pemberdayaan Perempuan dan Perlindungan Anak, 2015).

Hospitalisasi (rawat inap) pada pasien anak dapat menyebabkan kecemasan dan stres pada semua tingkatan usia. Penyebab kecemasan dipengaruhi oleh banyak faktor, 
baik dari faktor petugas (perawat, dokter dan tenaga kesehatan lainnya), lingkungan baru, maupun keluarga yang mendampingi selama perawatan. Keluarga sering merasa cemas dengan perkembangan keadaan anaknya, pengobatan dan biaya perawatan. Meskipun dampak tersebut tidak bersifat langsung terhadap anak, secara psikologis anak akan merasakan perubahan perilaku dari orang tua yang mendampingi selama perawatan (Nursalam et al., 2005). Perawatan di rumah sakit juga sering kali dipersepsikan anak sebagai hukuman sehingga anak akan merasa malu, bersalah, atau takut. Hal ini menimbulkan reaksi agresif dengan marah dan berontak, ekspresi verbal dengan mengucapkan kata-kata marah, tidak mau bekerja sama dengan perawat, apabila kondisi itu terjadi maka akan mempengaruhi proses perawatan saat di rumah sakit. Penelitian membuktikan bahwa hospitalisasi anak dapat menjadi suatu permasalahan yang menimbulkan trauma baik bagi anak maupun orang tua sehingga menimbulkan reaksi tertentu yang akan sangat berdampak pada kerjasama anak dan orang tua dalam perawatan anak selama di rumah sakit (Supartini, 2004).

Puskesmas Tampa Padang merupakan salah satu puskesmas perawatan di Kabupaten Mamuju. Berdasarkan hasil observasi peneliti di ruang rawat inap Puskesmas Tampa Padang jumlah pasien anak meningkat setiap tahunnya. Diperkirakan sejak tahun 2013 sampai 2015 pasien anak berjumlah 428 orang, dengan jumlah pasien anak pada tahun 2015 sebanyak 173 anak. Berdasarkan klasifikasi umur terdiri dari: usia $0-12$ bulan sebanyak 13 orang; usia 1 - 3 tahun sebanyak 39 orang, usia $4-6$ tahun sebanyak 28 orang, usia $7-12$ tahun sebanyak 48 orang, usia 13 - 18 tahun 43 orang. Kondisi anak yang dirawat sering gelisah, rewel dan selalu ingin ditemani saat menjalani proses perawatan. Anak juga sering menangis dan mengatakan ingin pulang. Penyebab kecemasan yang dialami beragam, mulai dari rasa cemas terhadap petugas kesehatan seperti dokter, perawat, dan bidan, serta tindakan medis, cemas karena nyeri yang dialami, rasa cemas karena berada pada tempat dan lingkungan baru, rasa cemas akibat perpisahan dengan saudaranya. Respon anak tersebut dapat menjadi kendala dalam pelaksanaan asuhan keperawatan yang akan diberikan sehingga menghambat proses penyembuhan dan mengakibatkan perawatan yang lebih lama bahkan akan mempercepat terjadinya komplikasi-komplikasi selama perawatan (Nursalam et al., 2005).

\section{METODE PENELITIAN \\ Jenis Penelitian}

Jenis penelitian yang digunakan dalam penelitian ini adalah deskriptif dengan rancangan cross sectional.

\section{Populasi dan Sampel}

Populasi dalam penelitian ini adalah semua anak yang dirawat di Ruang Rawat Inap Puskesmas Tampa Padang Kabupaten Mamuju. Subjek penelitian diambil secara purposive sampling, setelah diberikan informed consent dan memenuhi kriteria inklusi antara lain: anak yang berusia $1-3$ tahun, anak atau keluarga bisa diajak berkomunikasi, anak berdomisili di wilayah Kalukku.

Subjek penelitian berjumlah 63 orang. Penentuan besar sampel dalam penelitian ini menggunakan rumus Slovin (Sevilla \& Consuelo, 2007) sebagai berikut:

$$
\mathrm{n}=\frac{\mathrm{N}}{\mathrm{N}(\mathrm{d})^{2}+1}
$$

Keterangan :

$\mathrm{n}=$ Besar sampel

$\mathrm{N}=$ Besar populasi

$\mathrm{d}=$ Tingkat signifikansi $(0,1)$.

Dari rumus diatas dapat dihitung besar sampel yang akan diambil adalah:

$$
\begin{aligned}
& \mathrm{n}=\frac{173}{\mathrm{~N}(\mathrm{~d})^{2}+1} \\
& \mathrm{n}=\frac{173}{173(0,1)^{2}+1} \\
& \mathrm{n}=\frac{173}{2,73} \\
& \mathrm{n}=63
\end{aligned}
$$

\section{Teknik Pengumpulan Data}

Instrument yang digunakan dalam penelitian ini adalah kuesioner. Hospitalisasi dinilai dari lamanya hari rawat anak. Tingkat kecemasan diukur menggunakan lembar observasi Hamilton Rating Scale for Anxiety. 


\section{Analisa data}

Analisis data dilakukan dengan analisis deskriptif dengan menampilkan distribusi dan persentase dari tiap variabel. Selanjutnya dilakukan analisis untuk menguji hipotesis menggunakan fisher's exact test untuk mengetahui pengaruh hospitalisasi dengan tingkat kecemasan anak, dengan tingkat kepercayaan $95 \%(\alpha 0,05)$.
HASIL

Karakteristik Responden

Melihat tabel 1. berdasarkan umur responden paling banyak adalah berumur 2 tahun sebanyak 35 orang $(55.6 \%)$; responden berjenis kelamin terbanyak adalah perempuan berjumlah 35 orang (55.6\%); Agama responden terbanyak adalah Islam sebanyak 39 orang $(61.9 \%)$.

Tabel 1. Distribusi Frekuensi Karakteristik Responden ( $n=63)$

\begin{tabular}{llc}
\hline \multicolumn{1}{c}{ Karakteristik Responden } & n & Persen (\%) \\
\hline Umur reponden: & & \\
1 tahun & 17 & 26.9 \\
2 tahun & 35 & 55.6 \\
3 tahun & 11 & 17.5 \\
\hline Jenis kelamin responden: & & \\
$\quad$ Laki-laki & 28 & 44,4 \\
$\quad$ Perempuan & 35 & 55,6 \\
\hline Agama responden: & & \\
Islam & 39 & 61.9 \\
$\quad$ Kristen & 24 & 38.1 \\
\hline
\end{tabular}

Variabel Penelitian

Tabel 2. menunjukkan bahwa hospitalisasi responden terbanyak adalah cepat $(1-3$ hari $)$ sebanyak 59 orang (93.4\%); tingkat kecemasan anak paling banyak terdapat pada tidak cemas sebanyak 55 orang $(87.3 \%)$.

Tabel 2. Distribusi Variabel Penelitian Responden Di Ruang Rawat Inap Puskesmas Tampa Padang Kabupaten Mamuju (n=63)

\begin{tabular}{lcc}
\hline Variabel Penelitian & n & \% \\
\hline Hospitalisasi & 59 & \\
Cepat $(1-3$ hari $)$ & 4 & 93.4 \\
Lama $(4-5$ hari $)$ & & \\
\hline Tingkat Kecemasan & 55 & 87.3 \\
Tidak Cemas & 8 & 12.7 \\
Cemas &
\end{tabular}

\section{Analisis Bivariat}

Menggunakan uji statistik Pearson Fisher's Exact Test diperoleh hasil, bahwa ada pengaruh hospitalisasi dengan tingkat kecemasan anak dengan nilai $p=0,005$ (nilai $p<0,05$ ).

\section{PEMBAHASAN}

Hasil penelitian ini menunjukkan bahwa hosptalisasi mempengaruhi tingkat kecemasan anak. Hal ini sesuai dengan penelitian (Sari \& Sulisno, 2012) yang menyatakan bahwa anak yang mengalami hospitalisasi cenderung mengalami kecemasan. Kejadian kecemasan secara kuantitatif paling banyak terjadi padakecemasan tingkat ringan dan pada anak usia 4 tahun, laki-laki, dan telahdirawat 2 hari. Namun jika dilihat berdasarkan tingkat cemasnya, anakusia 3 tahun, perempuan, dan telah dirawat selama 2 hari di rumah sakit mengalami kecemasan lebih tinggi tingkatannya (kecemasan tingkat sedang). Anak perempuan lebih cemas daripada anak laki-laki karena anak perempuan lebih sensitif dan mendapat stressor lebih intensif 
dari pada anak laki-laki yang eksploratif. Hasil penelitian tidak mampu menjelaskan keterlibatan lamanya dirawat dengan kecemasan anak namun hasil penelitian menunjukkan bahwa anak paling banyak cemas ringan di hari pertama. Hal tersebut karena anak baru saja berpisah dari teman bermain, lingkungan tempat tinggal, hilang kendali,cedera dan nyeri, lingkungan baru saat hospitalisasi (Suliswati, 2005; Donna L. Wong, 2008).

Tabel 3. Hospitalisasi Mempengaruhi Tingkat Tecemasan Anak di Ruang Rawat Inap Puskesmas Tampa Padang Kabupaten Mamuju (n=63)

\begin{tabular}{|c|c|c|c|c|c|c|c|}
\hline \multirow{2}{*}{ Variabel } & \multicolumn{4}{|c|}{ Tingkat Kecemasan } & \multirow{2}{*}{$\mathbf{N}$} & \multirow{2}{*}{$\%$} & \multirow{2}{*}{$p$} \\
\hline & Tidak Cemas & $\%$ & Cemas & $\%$ & & & \\
\hline \multicolumn{8}{|l|}{ Hospitalisai } \\
\hline Cepat & 54 & 85.7 & 5 & 7.9 & 59 & 93.7 & 0,005 \\
\hline \multirow[t]{2}{*}{ Lama } & 1 & 1.60 & 3 & 4.8 & 4 & 6.3 & \\
\hline & 55 & 87.3 & 8 & 12.7 & 63 & 100 & \\
\hline
\end{tabular}

Respon anak yang dirawat di Ruang Rawat Inap Puskesmas Tampa Padang dapat diobservasi seperti sering gelisah, rewel dan selalu ingin ditemani saat menjalani proses perawatan. Anak juga sering menangis dan mengatakan ingin pulang. Penyebab kecemasan yang dialami beragam, mulai dari rasa cemas terhadap petugas kesehatan seperti dokter, perawat, dan bidan, serta tindakan medis, cemas karena nyeri yang dialami, berada pada tempat dan lingkungan baru dan rasa cemas akibat perpisahan dengan saudaranya. Hal ini sesuai dengan teori yang menyatakan hospitalisasi dapat dianggap sebagai suatu pengalaman yang mengancam dan merupakan sebuah stressor, serta dapat menimbulkan krisis bagi anak dan keluarga. Hal ini mungkin terjadi karena anak tidak memahami mengapa dia dirawat, stres dengan adanya perubahan akan status kesehatan, lingkungan dan kebiasaan seharihari dan keterbatasan mekanisme koping. Menurut Alimul (2005) anak akan memberikan reaksi saat sakit dan mengalami proses hospitalisasi. Reaksi tersebut dipengaruhi oleh tingkat perkembangan, pengalaman sebelumnya, support system dalam keluarga, keterampilan koping dan berat ringannya penyakit. Menurut Wong (2003) perasaan merupakan respons emosional yang dapat diakibatkan oleh cemas akibat perpisahan, kehilangan kendali, cedera tubuh dan nyeri. Kecemasan yang timbul merupakan respon emosional terhadap penilaian sesuatu yang berbahaya, berkaitan dengan perasaan tidak pasti dan tidak berdaya (Stuart \& Sundeen, 2010).
Menurut Wong (2003), stres utama dari masa bayi pertengahan sampai usia prasekolah, terutama untuk anak-anak yang berusia 6 bulan sampai 30 bulan adalah kecemasan akibat perpisahan yang disebut sebagai depresi anaklitik. Pada kondisi cemas akibat perpisahan anak akan memberikan respon berupa perubahan perilaku. Manifestasi kecemasan yang timbul terbagi menjadi tiga fase yaitu: (a) fase protes (phase of protest) anak-anak bereaksi secara agresif dengan menangis dan berteriak memanggil orang tua, menarik perhatian agar orang lain tahu bahwa ia tidak ingin ditinggalkan orang tuanya serta menolak perhatian orang asing atau orang lain dan sulit ditenangkan; (b) fase putus asa (phase of despair) dimana tangisan akan berhenti dan muncul depresi yang terlihat adalah anak kurang begitu aktif, tidak tertarik untuk bermain atau terhadap makanan dan menarik diri dari orang lain; dan (c) fase menolak (phase of denial) merupakan fase terakhir yaitu fase pelepasan atau penyangkalan, dimana anak tampak mulai mampu menyesuaikan diri terhadap kehilangan, tertarik pada lingkungan sekitar, bermain dengan orang lain dan tampak membentuk hubungan baru, meskipun perilaku tersebut dilakukan merupakan hasil dari kepasrahan dan bukan merupakan kesenangan.

Responden pada penelitian ini adalah anak toddler (umur $1-3$ tahun), sehingga kita dapat melihat beberapa respon kecemasan seperti di atas. Hal ini sesuai dengan teori Ericson dalam (Price \& Gwin, 2005), bahwa pada fase ini anak sedang mengembangkan kemampuan otonominya. Akibat sakit dan 
dirawat di rumah sakit, anak akan kehilangan kebebasan dalam mengembangkan otonominya. Keterbatasan aktifitas, kurangnya kemampuan untuk memilih dan perubahan rutinitas dan ritual akan menyebabkan anak merasa tidak berdaya. Toddler bergantung pada konsistensi dan familiaritas ritual harian guna memberikan stabilitas dan kendali selama masa pertumbuhan dan perkembangan. Area toddler dalam hal ritual mencakup makan, tidur, mandi, toileting dan bermain. Jika rutinitas tersebut terganggu, maka dapat terjadi kemunduran terhadap kemampuan yang sudah dicapai atau disebut dengan regresi (Wong, 2003).

Pemahaman toddler tentang citra tubuh, terutama definisi batasan tubuh, perkembangannya masih sangat buruk. Pengalaman intrusif seperti pemeriksaan telinga atau mulut atau pemeriksaan suhu rektal merupakan prosedur yang sangat mencemaskan dan toddler bereaksi sama kerasnya dengan prosedur yang menyakitkan. Secara umum, anak dalam kelompok usia ini terus bereaksi dengan kemarahan emosional yang kuat dan resistensi fisik terhadap pengalaman nyeri baik yang aktual maupun yang dirasakan. Perilaku yang mengindikasikan nyeri antara lain, meringis kesakitan, mengatupkan gigi dan atau bibir, membuka mata lebar-lebar, mengguncang-guncang, menggosok-gosok, dan bertindak agresif, seperti menggigit, menendang, memukul, atau melarikan diri. Tidak seperti orang dewasa yang biasanya mengurangi aktifitasnya pada saat nyeri, anakanak cenderung lebih gelisah dan sangat aktif, seringkali respon ini tidak diketahui sebagai akibat dari nyeri. Diakhir periode ini, toddler biasanya mampu mengkomunikasikan nyeri dengan cara menunjuk area spesifik nyeri yang mereka rasakan, meskipun begitu anak belum mampu menggambarkan jenis dan intensitas nyeri (Utami, 2014).

Penelitian lain yang menunjukkan bahwa hospitalisasi mempengaruhi tingkat kecemasan anak adalah penelitin yang dilakukan oleh (Nursondang, Setiawati, \& Elliya, 2015). Kecemasan yang diakibatkan oleh proses hospitalisasi dapat diminimalkan dengan adanya dukungan keluarga. Selain dukungan keluarga cara lain untuk menurunkan kecemasan anak dapat dilakukan dengan terapi bermain, hal ini sesuai dengan hasil penelitian (Solikhah, 2011) yang menyatakan bahwa terjadi penurunan tingkat kecemasan sesudah dilakukan therapeutic peer play.

Berdasarkan hasil penelitian ini penulis melihat perlu upaya dari berbagai pihak untuk memenuhi standar pelayanan minimal di puskesmas, khususnya pelayanan rawat inap bagi pasien anak. Beberapa upaya yang dapat dilakukan oleh perawat untuk mengatasi masalah ketakutan dan kecemasan anak akibat hospitalisasi antara lain:

1. Pendekatan kepada orang tua dan anak.

Pendekatan yang dapat dilakukan perawat kepada orang tua dan anak adalah dengan memberikan penjelasan setiap melakukan tindakan, selalu berkomunikasi tentang perkembangan kesehatan anak, dan memberikan motivasi pada orang tua dan anak untuk mengatasi ketakutan dan kecemasannya.

2. Memberi lingkungan yang aman dan nyaman.

Memberi lingkungan yang aman pada anak misalnya lingkungan yang terhindar dari bahaya seperti jatuh dari tempat tidur, keluarga atau orang terdekat selalu ada dekat anak. Perawat dapat berkolaborasi dengan keluarga dalam perawatan anak. Selain lingkungan yang aman juga nyaman bagi pasien seperti membatasi pengunjung sehingga anak dapat beristirahat.

3. Menyediakan mainan

Puskesmas harus menyediakan mainan dan arena bermain untuk pasien anak. Proses asuhan keperawatan dapat dilakukan dengan metode bermain. Jika puskesmas tidak mempunyai fasilitas bermain bagi anak, perawat harus kreatif membuat mainan dari alat atau bahan sederhana yang tersedia di lingkungan puskesmas. Selain itu keluarga juga boleh membawakan mainan kesukaan anak dari rumah.

Diharapkan dengan upaya ini dapat mengatasi ketakutan dan kecemasan anak selama proses hospitalisasi.

\section{KESIMPULAN DAN SARAN}

Ada pengaruh hospitalisasi terhadap tingkat kecemasan anak di Ruang Rawat Inap Puskesmas Tampa Padang Kabupaten Mamuju. Diharapkan agar petugas kesehatan khususnya perawat dapat meminimalkan tingkat kecemasan anak selama hospitalisasi dengan terus menjaga komunikasi pada anak dan keluarga, menciptakan lingkunan yang aman 
dan nyaman serta menyediakan mainan, sehingga anak merasa nyaman selama proses hospitalisasi.

\section{DAFTAR PUSTAKA}

Alimul, A. A. (2005). Pengantar Ilmu Keperawatan Anak (1st ed.). Jakarta: Salemba Medika.

Kementerian Pemberdayaan Perempuan dan Perlindungan Anak. (2015). Profil Anak Indonesia 2015. Kementerian Pemberdayaan Perempuan dan Perlindungan Anak serta Badan Pusat Statistik. Ja: Kementerian Pemberdayaan Perempuan dan Perlindungan Anak serta Badan Pusat Statistik.

Nursalam, N., Susilaningrum, R., \& Utami, S. (2005). Asuhan Keperawatan Bayi dan Anak (untuk Perawat dan Bidan) (Edisi 1). Jakarta: Salemba Medika.

Nursondang, S., Setiawati, S., \& Elliya, R. (2015). Hubungan Dukungan Keluarga dengan Tingkat Kecemasan Akibat Hospitaliasi Pada Anak Usia Pra Sekolah di Ruang Alamanda RSUD dr. H. Abdul Moeloek Provinsi Lampung Tahun 2014. Jurnal Kesehatan Holistik, 9(2), 59-63.

Price, D. L., \& Gwin, J. F. (2005). Thompson's Pediatric Nursing an Introductory Text (9th ed.). St. Louis: Elsevier Inc.
Sari, F. S., \& Sulisno, M. (2012). Hubungan Kecemasan Ibu dengan Kecemasan Anak Saat Hospitalisasi Anak. Jurnal Nursing Studies, 1(1), 51-59.

Sevilla, S., \& Consuelo, G. (2007). Research Methods. Quezon City: Rex Printing Company.

Solikhah, U. (2011). Therapeutic Peer Play sebagai Upaya Menurunkan Kecemasan Anak Usia Sekolah Selama Hospitalisasi. Jurnal Keperawatan Soedirman, 6(1), 20-30.

Stuart, G. ., \& Sundeen, S. . (2010). Buku Saku Keperawatan Jiwa (3rd ed.). Jakarta: EGC.

Suliswati, S. (2005). Konsep Dasar Keperawatan Kesehatan Jiwa. Jakarta: EGC.

Supartini, Y. (2004). Buku Ajar Konsep Dasar Keperawatan Anak. Jakarta: EGC.

Utami, Y. (2014). Dampak Hospitalisasi terhadap Perkembangan Anak. Jurnal Ilmiah Widya, 2(2), 9-20.

Wong, D. (2003). Whaley and Wong's Nursing Care of Infants and Children (7th ed.). St. Louis: Mosby.

Wong, D. L. (2008). Buku Ajar Keperawatan Pediatrik. Jakarta: EGC. 